\title{
PENGEMBANGAN SAPI POTONG MELALUI PENERAPAN TEKNOLOGI DETEKSI KEBUNTINGAN DINI DAN INOVASI PAKAN RAMAH LINGKUNGAN PADA KELOMPOK TANI DI LANGGAM, PASAMAN BARAT
}

\author{
Ferry Lismanto Syaiful $^{1 *}$, Fauzia Agustin ${ }^{1)}$, Rusman Ningrat $^{1)}$, Uyung Gatot S. Dinata $^{2)}$ \\ dan Efrizal ${ }^{3)}$ \\ ${ }^{1)}$ Fakultas Peternakan Universitas Andalas \\ ${ }^{2)}$ Fakultas Teknik Universitas Andalas \\ ${ }^{3)}$ Fakultas MIPA Universitas Andalas \\ ${ }^{*}$ Email : ferrylismanto5@gmail.com
}

\begin{abstract}
ABSTRAK
Kabupaten Pasaman Barat merupakan daerah yang memiliki potensi lahan perkebunan maupun pertanian yang cukup luas. Daerah Langgam merupakan salah satu nagari di Kecamatan Kinali Kabupaten Pasaman Barat yang memiliki daya dukung lahan berupa lokasi yang luas. Daerah ini cocok untuk pemeliharaan sapi potong yang bisa memberikan keuntungan yang baik bagi peternak jika dikelolah dengan manajemen yang baik. Disamping itu daya dukung lahan yang luas berpotensi untuk pengembangan usaha sapi potong. Namun disuatu sisi, potensi yang dimiliki daerah ini belum tergali secara optimal dan rendahnya pengetahuan peternak dalam inovasi teknologi pengembangan ternak. Kegiatan ini bertujuan untuk 1. meningkatkan pengetahuan dan keterampilan peternak dalam budidaya sapi potong yang baik dan menguntungkan, 2. meningkatkan pengetahuan dan keterampilan peternak tentang teknologi deteksi kebuntingan dini sapi potong dan 3. meningkatkan pengetahuan dan keterampilan peternak dalam formulasi ransum dan inovasi pakan yang ramah lingkungan. Metode kegiatan meliputi penyuluhan, demonstrasi dan pelatihan tentang deteksi kebuntingan dini, formulasi ransum dan inovasi pakan yang ramah lingkungan berupa teknolosi silase dan pakan komplit. Sedangkan mitra yang terlibat dalam kegiatan ini adalah kelompok tani Karya Muda dan Usaha Muda di daerah Langgam, Pasaman Barat. Kelompok Tani Karya Muda dan Usaha Muda ini memiliki ternak sapi potong sebanyak 200 ekor berupa sapi Bali yang pemeliharaannya secara semi intensif. Hasil kegiatan adalah peternak meningkat pengetahuannya tentang teknik budidaya sapi potong yang baik yang berbasis menguntungkan dan mampu melakukan teknologi deteksi kebuntingan dini pada sapi potong mereka. Disamping itu, peternak juga meningkat kemampuannya dalam formulasi ransum sehingga kebutuhan nutrisi ternak dapat terpenuhi sesuai standar kebutuhan ternak. Lebih lanjut, peternak mampu pemanfaatan limbah pertanian dan pengolahannya melalui teknologi inovasi pakan ramah lingkungan berupa teknolosi silase dan pakan komplit sebagai pakan ternak. Kesimpulan dari kegiatan ini adalah pelaksanaan kegiatan ini dikategorikan sukses dalam pencapaian target yang direncanakan dan peserta/ peternak pun sangat antusias mengikuti pelaksanaan kegiatan ini. Kegiatan yang dilakukan sanagt bermanfaat dan berhasil dalam mentransfer pengetahuan dan meningkatkan keterampilan peternak.
\end{abstract}

Kata Kunci : deteksi kebuntingan dini, inovasi pakan, ramah lingkungan, kelompok tani, sapi potong

\section{Beef Cattles Development Through The Implementation of Early Detection Pregnant of Technology and Environmentally Friendly Feed Innovation for Farmers in Langgam, West Pasaman}

\begin{abstract}
West Pasaman regency is an area that has a large potential of plantation and agricultural land. Langgam area is one of the nagari in Kinali District, West Pasaman Regency, which has a land carrying capacity in the form of a large location. This area is suitable for the maintenance of beef cattle that can provide good benefits for farmers if managed with good management. Besides that, the large carrying capacity of the land has the potential to develop beef cattle business. But on the one hand, the potential of this region has not been optimally explored and the knowledge of farmers is low in livestock development
\end{abstract}


technology innovation. This activity aims to 1 . improve the knowledge and skills of farmers in good and profitable beef farming, 2. increase the knowledge and skills of farmers about the technology of early pregnancy detection of beef cattle and 3. increase farmers' knowledge and skills in ration formulation and friendly feed innovation environment. The method of activities included counseling, demonstration and training on early pregnancy detection, ration formulation and environmentally friendly feed innovations in the form of silage technolosi and complete feed. While the partners involved in this activity are Karya Muda and Young Business farmer groups in the Langgam area, West Pasaman. The Young Karya and Young Enterprises Farmers Group has as many as 200 beef cattle in the form of Balinese cattle which are semi-intensive. The results of the activity were increased breeders' knowledge of good beef-based farming techniques that were profitable and able to carry out early pregnancy detection technology in their beef cattle. Besides that, breeders also increase their ability in the formulation of rations so that the nutritional needs of livestock can be fulfilled according to the standards of livestock needs. Furthermore, breeders are able to utilize agricultural waste and their processing through innovative technology of environmentally friendly feed in the form of silage technolosi and complete feed as animal feed. The conclusion of this activity is that the implementation of this activity is categorized as successful in achieving planned targets and the participants / breeders were very enthusiastic in participating in the implementation of this activity. The activities carried out were useful and successful in transferring knowledge and improving the skills of farmers.

Keywords: early pregnancy detection, feed innovation, environmentally friendly, farmer groups, beef cattle

\section{PENDAHULUAN}

Kabupaten Pasaman Barat merupakan daerah yang memiliki potensi lahan cukup luas berupa lahan perkebunan dan pertanian. Langgam merupakan salah satu daerah di Kinali, Pasaman Barat yang memiliki daya dukung lahan berupa lokasi yang luas. Daerah ini cocok untuk pemeliharaan sapi potong yang bisa memberikan keuntungan yang baik bagi peternak jika dikelolah dengan manajemen yang baik.

Disamping itu daya dukung lahan luas yang dimiliki berpotensi untuk pengembangan usaha sapi potong. Sapi potong merupakan sapi yang dipelihara dengan tujuan utama sebagai penghasil daging. Sapi potong memiliki ciri-ciri adalah sebagai berikut: tubuh besar, berbentuk persegi empat atau balok, kualitas dagingnya maksimum dan mudah dipasarkan, laju pertumbuhan cepat, cepat mencapai dewasa, efisiensi pakannya tinggi (Santosa, 1995). Menurut Abidin (2006), sapi potong adalah jenis sapi khusus dipelihara untuk digemukkan karena karakteristiknya, seperti tingkat pertumbuhan cepat dan kualitas daging cukup baik. Sapi-sapi ini umumnya dijadikan sebagai sapi bakalan, dipelihara secara intensif selama beberapa bulan, sehingga diperoleh pertambahan bobot badan ideal untuk dipotong.

Namun, potensi yang dimiliki daerah ini belum tergali secara optimal, hal ini disebabkan belum tersedianya sumberdaya manusia yang memadai untuk pengembangan ternak sapi. Disamping itu, lahan pertanian yang luas dimiliki maka daerah ini sangat cocok dilakukan usaha tani. Daerah ini banyak terdapat limbah pertanian/ jerami padi dan jagung serta sawit. Namun limbah pertanian jerami selama ini tidak pernah dimanfaatkan.

Disisi lain, saat ini umumnya pemeliharaan ternak dilakukan petani/ peternak masih seadanya baik dalam pemberian makanan maupun dalam manajemen pemeliharaan pada umumnya. Penyediaan pakan dari segi kualitas, kuantitas maupun dari kesinambungan di daerah ini sangat fluktuatif. Lebih lanjut, pengetahuan peternakan 
akan reproduksi ternak / deteksi kebuntingan dini ternak juga rendah. Rendahnya pengetahuan peternak akan pakan dan deteksi kebuntingan dini sehingga akan berdampak terhadap produktivitas sapi. Produktivitas ternak sangat bergantung pada tiga faktor utama yaitu perkawinan (breeding), pemberian pakan (feeding), dan manajemen. Rendahnya pengetahuan peternak produktivitas ternak sehingga menyebabkan terkendala dalam pengembangan usaha peternakan sapi.

Berdasarkan hasil evaluasi bahwa pemeliharaan ternak sapi potong di kelompok tani "Karya Muda" dan "Karya Baru" ini memiliki ternak sapi potong sebanyak 200 ekor berupa sapi Bali yang pemeliharaannya secara semi intensif, pemberian rumput secara "cut and carry". Pakan hijauan yang diberikan hanya berupa rumput lapangan, sedangkan konsentrat diberikan pada ternak berupa kulit ubi kayu yang ketersediaannya berfluktuasi. Walaupun kelompok tani ternak sapi ini telah berusaha untuk mencukupi kebutuhan pakan ternaknya, namun jika ditinjau dari segi kecukupan nutrisinya, ternyata masih belum memenuhi. Hal ini disebabkan peternak belum mengetahui bagaimana formulasi ransum yang baik yang dapat meningkatkan produksi ternak sapi sesuai dengan yang diharapkan.

Untuk meningkatkan populasi ternak sapi di daerah Kinali, Pasaman barat maka perlu dilakukan budidaya sapi potong yang basik dan berbasis mengutungkan. Penyuluhan dan pendampingan teknis budidaya sapi potong yang tepat yang memenuhi standar Good Farming Practice (GFP). Disamping itu, manajemen reproduksi merupakan faktor yang tidak kalah penting dibandingkan pemeliharaan itu sendiri. Untuk mendapatkan manajemen reproduksi yang optimal dibutuhkan metode deteksi kebuntingan yang efektif dan efisien pada ternak dalam meningkatkan produktivitas ternak.

Disamping itu, deteksi kebuntingan ternak merupakan suatu hal yang sangat penting dilakukan setelah ternak dikawinkan. Secara umum, deteksi kebuntingan dini diperlukan dalam hal mengindentifikasi ternak yang tidak bunting segera setelah perkawinan atau inseminasi, sehingga waktu produksi yang hilang karena infertilitas dapat ditekan dengan penanganan yang tepat seperti ternak harus dijual atau dilakukan culling. Hal ini bertujuan menekan biaya pada program breeding dan membantu manajemen ternak secara ekonomis (Samsudewa et al., (2003); Syaiful dkk (2018).

Pengelolaan bahan pakan yang berasal dari limbah pertanian dengan teknologi amoniasi, silase dan fermentasi dapat meningkatkan kualitas limbah pertanian tersebut dan apabila dikonsumsi oleh sapi akan memberikan nilai biologis yang relative tinggi.

Menurut Syaiful dkk (2018); Sowmen dkk (2018), pemanfaatan jerami padi dapat digunakan sebagai alternatif pengganti hijauan melalui teknologi amoniasi dan fermentasi jerami memanfaatkan potensi daerah setempat. Ditambahkan Syaiful dkk (2018), Penggunaan limbah pertanian selain untuk pakan dapat juga diolah untuk bahan bakar kompor sekam dapat digunakan dalam kehidupan sehari-hari untuk menghemat biaya dan mengatasi kelangkaan dan mahalnya gas elpiji maupun minyak tanah. Selain hijauan juga diperlukan bagaimana cara penerapan teknologi ransum komplit dan memformulasi ransum yang sesuai kebutuhan ternak. Peningkatan nilai biologis pakan tidak hanya dapat dicapai dengan pengolahan pakan saja tetapi dapat lebih ditingkatkan dengan pemberian pakan tertentu dan ini dapat diwujudkan dengan membuat formulasi ransum yang tepat dengan harapan dapat meningkatkan perekonomian rakyat. 


\section{METODE}

\section{Metode Consuling}

Metode yang ditawarkan dalam mendukung pelaksanaan program adalah metode consuling. Sebelumnya dilakukan pendekatan kemudian diberikan penyuluhan, pelatihan dan pembinaan tentang budidaya ternak sapi potong dan deteksi kebuntingan dini serta inovasi teknologi pakan untuk peningkatan produktivitas sapi potong.

Kegiatan ini ditujukan kepada kelompok tani Karya Muda dan Karya Baru serta masyarakat di daerah Langgam, Pasaman Barat. Adapun anggota kelompok tani yang terlibat masing-masing sebanyak 20 orang dari setiap kelompok.

\section{Prosedur Kegiatan}

Prosedur pelaksanaan kegiatan yang dilakukan adalah;

\section{a. Penyuluhan}

Penyuluhan dilakukan pada khalayak sasaran secara langsung dengan memberikan kesempatan untuk menyampaikan gagasan-gagasan yang ingin dikemukakan. Penyuluhan diberikan tentang budidaya dan deteksi kebuntingan dini pada sapi potong. Disamping itu juga dibahas tentang inovasi teknologi pakan berbasis bahan lokal terhadap limbah pertanian yang dimiliki daerah setempat. Untuk lebih memudahkan penyampai materi ceramah kepada peserta juga dibagikan penuntun praktis beternak sapi potong dan teknis inovasi pakan yang ramah lingkungan.

\section{b. Percontohan/ Pelatihan}

Dilakukan percontohan dan pelatihan tentang: 1). Teknik pemilihan bibit yang baik, 2). Teknik reproduksi sapi dan deteksi kebutingan dini sapi potong, 3). teknik pembuatan ransum komplit, 4). teknik pembuatan dan pengadukan ransum konsentrat, dan 5). teknik pembuatan silase jagung.

\section{c. Bimbingan dan Pembinaan}

Setelah mendapatkan penyuluhan dan pelatihan.Selanjutnya mitra akan dibimbing dan dibina agar mereka dapat menerapkan perbaikan tatalaksana pemeliharaan sapi potong dan inovasi teknologi pakan. Monitoring dilakukan secara berkala (1x2 minggu). Diskusi dan konsultasi dilakukan saat monitoring untuk mencari solusi dari berbagai kendala yang dihadapi.

\section{d. Evaluasi dan Pelaporan}

Evaluasi dilakukan terhadap 2 aspek yaitu aspek pengetahuan peternak dan aspek efektifitas pelaksanaan dari teknologi yang diberikan. Pengetahuan peternak setelah mendapat penyuluhan diukur dengan membandingkan hasil yang diperoleh dari kuesioner yang diberikan sebelum atau diawal penyuluhan dengan pengetahuan diakhir penyuluhan. Aspek pelaksanaan diukur dengan mengetahui tingkat keberhasilan dari teknologi yang diberikan atau diterapkan lalu pada akhir kegiatan akan dilakukan evaluasi.

\section{e. Partisipasi Mitra}

Untuk mensukseskan pelaksanaan kegiatan ini diharapkan mitra berpartisipasi akatif dalam beberapa hal, yaitu; 


\section{Antusias dan serius dalam pelaksanaan kegiatan}

Pelaksanaan kegiatan ini dimulai dari kegiatan penyuluhan, pelatihan dan bimbingan/ pembinaan, monitoring dan evaluasi yang akan dilaksanakan oleh Tim Pelaksana. Agar pelaksanaan kegiatan ini terlaksana dengan baik diharapkan keseriusan mitra dalam mengikuti prosesi kegiatan untuk memberdayakan mitra menjadi mandiri dan dapat di capai dengan baik.

\section{Motivasi yang Tinggi}

Motivasi dan keinginan yang kuat akan tercipta dengan adanya pelatihan motivasi yang diberikan diharapkan kegiatan ini dapat membangkitkan usaha mitra.

\section{Kepastian Pelestarian/ Keberlanjutan Program Kegiatan.}

Setelah kegiatan selesai dilaksanakan mitra membuat jadwal kegiatan pertemuan rutin yang berguna sebagai forum diskusi mencari solusi dalam mengatasi permasalahan yang dihadapi. Selanjutnya memonitor kemajuan program yang telah dicapai dalam pelaksanaan kegiatan ini. Disamping itu setelah kegiatan ini berakhir, diharapkan mitra dapat mempertahankan serta adanya keberlanjutan dari program kegiatan ini.

\section{HASIL DAN PEMBAHASAN}

Berdasarkan hasil pelaksanaan kegiatan yang telah dilakukan, tampak begitu besarnya animo peternak/ kelompok tani dan masyarakat di daerah Kinali, Pasaman Barat terhadap usaha peternakan sapi potong. Hal ini tampak pada saat pelaksanaan kegiatan, begitu banyaknya yang turut hadir di acara tersebut yang terdiri dari bapakbapak, ibu-ibu, juga kalangan anak muda. Adapun yang hadir saat itu ternyata tidak semuanya dari kalangan peternak, namun masyarakat yang memiliki ternak juga ikut dan antusias dalam pelaksanaan kegiatan.

\section{Budidaya Sapi Potong yang Baik Berbasis Menguntungkan}

Produktivitas ternak sangat bergantung pada tiga faktor utama yaitu perkawinan (breeding), pemberian pakan (feeding), dan manajemen. Manajemen pemeliharaan menjadi salah satu faktor penting karena bersentuhan langsung dengan ternak. Untuk meningkatkan produktivitas sapi dapat dilakukan melalui pakan, program pemuliaan, perbaikan efisiensi reproduksi, perbaikan tatalaksana pemeliharaan, dan perawatan. (Inounu et al., 2002).

Saat ini, peluang beternak sapi potong masih tetap terbuka, hal ini disebabkan karena permintaan daging sapi yang terus menerus menunjukkan peningkatan. Pemeliharan sapi potong dapat dibagi atas dua tujuan yaitu usaha penggemukan dan pembibitan. Usaha pembibitan sapi potong merupakan usaha yang cukup potensial dikembangkan di masyarakat mengingat pemeliharaan tidak membutuhkan penanganan yang banyak membutuhkan waktu atau intensif. Sehingga cocok untuk dikembangkan di desa-desa dimana sebagian peternakan masih menjadi usaha sampingan selain bertani. Pada usaha penggemukkan diperlukan perhatian yang lebih serius agar diperoleh keuntungan yang banyak.

Pada usaha pembibitan sapi potong keuntungan yang diperoleh terutama dari anak yang dilahirkan dan juga kenaikan harga induk. Untuk mendapatkan keuntungan yang 
banyak terutama dari kelahiran anak diperlukan syarat-syarat tertentu seperti makanan yang cukup, bibit yang baik dan waktu mengawinkan sapi yang tepat setelah melahirkan.
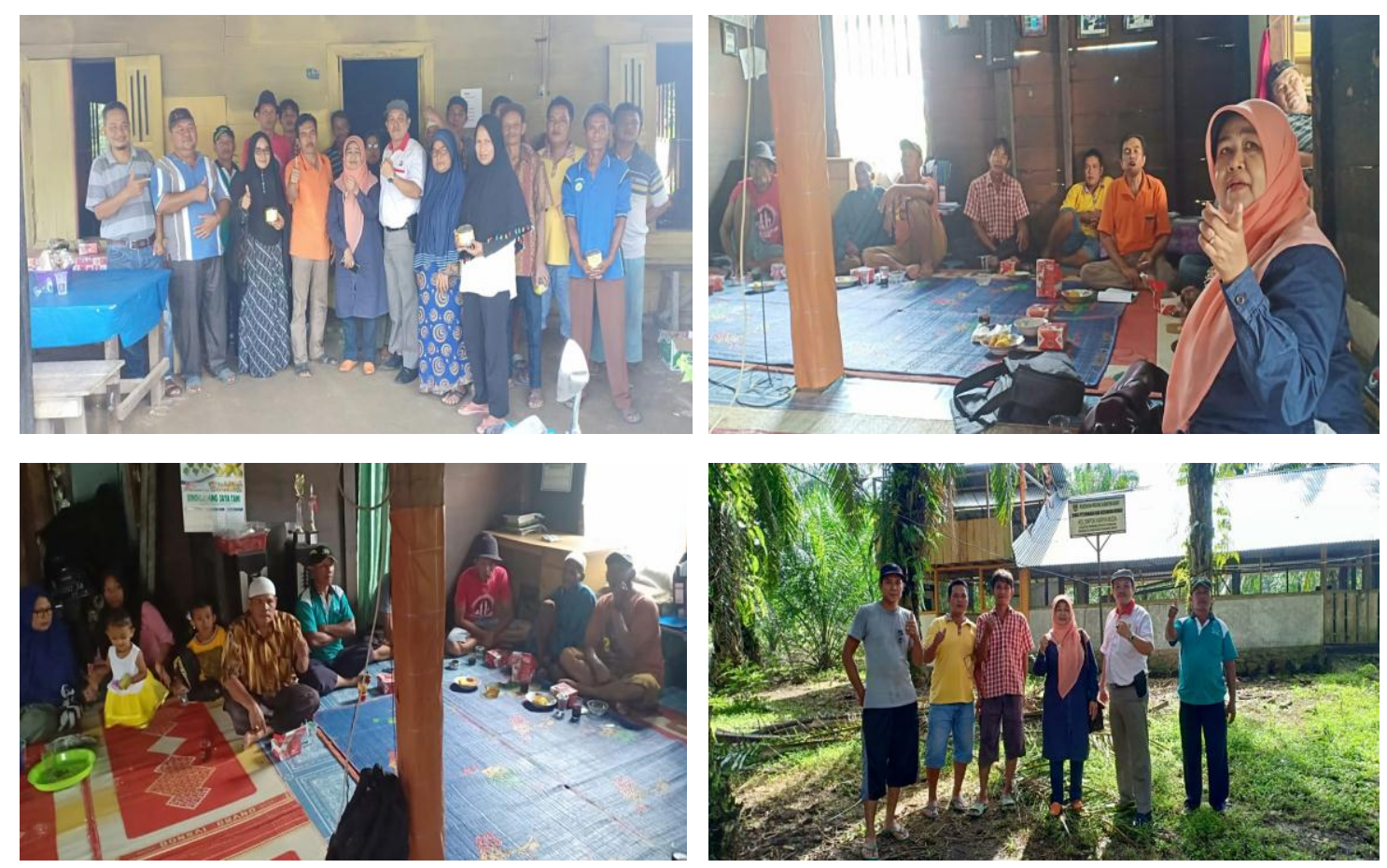

Gambar 1. Penyuluhan Budidaya Sapi Potong Berbasis Menguntungkan

\section{Teknologi Deteksi Kebuntingan Dini Sapi Potong}

Manajemen reproduksi merupakan faktor yang tidak kalah penting dibandingkan pemeliharaan itu sendiri. Untuk mendapatkan manajemen reproduksi yang optimal dibutuhkan metode deteksi kebuntingan yang efektif dan efisien pada ternak dalam meningkatkan produktivitas ternak. Deteksi kebuntingan merupakan suatu hal yang sangat penting dilakukan setelah ternak dikawinkan. Secara umum, deteksi kebuntingan dini diperlukan dalam hal mengindentifikasi ternak yang tidak bunting segera setelah perkawinan atau inseminasi, sehingga waktu produksi yang hilang karena infertilitas dapat ditekan dengan penanganan yang tepat seperti ternak harus dijual atau dilakukan culling. Hal ini bertujuan menekan biaya pada program breeding dan membantu manajemen ternak secara ekonomis (Samsudewa et al., (2003); Syaiful dkk (2018).

Melihat realitas di lapangan para peternak memelihara ternaknya yang sudah di lakukan inseminasi/ IB masih standarisasi pemahamannya mengenai kapan waktu dan secepat mungkin untuk melaporkan dalam periksaan kebuntingan pada ternak sapi yang dipelihara, yang terkadang tidak semua ternak sapi yang IB positif bunting, dalam hal ini harus dilakukan pemeriksaan kebuntingan dini.

Deteksi kebuntingan dini pada ternak sangat penting bagi sebuah manajemen reproduksi sebagaimana ditinjau dari segi ekonomi. Mengetahui bahwa ternaknya bunting atau tidak mempunyai nilai ekonomis yang perlu dipertimbangkan sebagai hal penting bagi manajemen reproduksi yang harus diterapkan. Pemilihan metode tergantung pada spesies, umur kebuntingan, biaya, ketepatan dan kecepatan diagnosa. 
Pemeriksaan/ diagnosa kebuntingan adalah salah satu cara dengan menggunakan metode khusus untuk menentukan keadaan hewan bunting atau tidak. Palpasi rektal adalah metode diagnosa kebuntingan yang dapat dilakukan dengan tepat pada ternak besar seperti kuda, kerbau dan sapi. Dalam hal ini yang ingin dilakukan adalah palpasi rektal pada umur kebuntingan dini karena metode ini adalah salah satu dari beberapa metode yang sering dilakukan dan tanpa memakan biaya dan tenaga yang cukup lama, tetapi yang sering dilakukan adalah palpasi pada umur kebuntingan tua. Keterampilan untuk menentukan kebuntingan secara dini sangat perlu untuk dimiliki, dalam hal ini semakin cepat kita mengetahui ternak itu bunting atau tidak bunting maka semakin baik.

Mengingat hal ini waktu yang menjadi tolak ukur dalam manajemen pemeliharaan ternak yang hanya akan mendatangkan kerugian bagi para peternak, maka salah satu aletrnatifnya melakukan deteksi kebuntingan dini, dengan diketahuinya status kebuntingan dalam waktu yang lebih cepat dan akurat, peternak dapat mengambil tindakan lanjutan, misal menyesuaikan pakan apabila induk bunting atau menjual ternaknya apabila tidak bunting akibat infertilitas, sehingga peternak tidak akan mengalami kerugian yang besar akibat biaya pemeliharaan yang dikeluarkan pada sapi yang di Inseminasi.

Untuk diketahui deteksi kebuntingan secara dini dengan teknik palpasi rektal dan USG dapat digunakan yakni eksplorasi rectal adalah palpasi/meraba uterus melalui dinding rectum (anus) untuk meraba apakah terjadi pembesaran yang terjadi selama kebuntingan atau adanya membrane fetus maupun fetus. Teknik ini hasilnya dapat diketahui dan cukup akurat namun harus dilakukan oleh tenaga profesional seperti inseminator maupun dokter hewan. Disamping itu metode deteksi kebuntingan pada ternak sapi dilakukan secara konvensional yaitu dengan pengecekan fisik secara langsung (perogohan/palpasi rectal) yang hanya bisa dilakukan 60 hari setelah inseminasi. Sedangkan USG dapat digunakan untuk mendeteksi kebuntingan secara dini yakni menggunakan probe yang dapat mendeteksi adanya perubahan di dalam rongga abdomen yakni bentuk dan ukuran dari comua uteri. Alat ini dapat juga digunakan untuk mendeteksi adanya gangguan reproduksi, kematian embrio dini, jenis kelamin pedet maupun abnormalitas pedet, akan tetapi harganya cukup mahal dan memerlukan operator yang sudah terlatih.

Menurut Syaiful (2018), deteksi kebuntingan dini pada sapi lokal dapat dilakukan dengan metode punyakoti dengan tingkat kebuntingan mencapai $80 \%$ pada kebuntingan 60 hari setelah di IB. Adanya teknologi tes kit deteksi kebuntingan dini ini tentunya akan memberikan peluang untuk mengetahui sapi bunting pada usia kebuntingan dini. Teknologi tes kit deteksi kebuntingan dini dapat digunakan untuk mengetes kebuntingan sapi yang sudah diinseminasi (Gambar 2). Penggunaan tes kit deteksi kebuntingan dini sapi ini dapat dilakukan lebih dini dan tanpa beresiko serta tidak membutuhkan skill. Disamping itu, uji deteksi kebuntingan hanya membutuhkan urine sapi saja untuk mendeteksi kebuntingan dengan akurasi yang sangat tinggi. Disamping itu, waktu deteksi kebuntingan sangat singkat yang membutuhkan waktu deteksi hanya dalam 1 menit dan keunggulan lainnya dapat mendeteksi usia kebuntingan sapi dalam 2-3 minggu.

Dari segi biaya, penggunaan tes kit deteksi kebuntingan dini ini jauh lebih ekonomis dibandingkan palpasi rektal. Untuk pengecekan kebuntingan dengan palpasi rektal, biasanya peternak harus mengeluarkan biaya Rp 35.000 s/d 50.000 per deteksi. Sedangkan penggunaan test kit kebuntingan dini ini, peternak hanya membutuhkan 
biaya Rp 6.000 per deteksi.

Deteksi kebuntingan dini pada sapi induk ini dapat meningkatkan efisiensi reproduksi sehingga dapi induk yang diketahui belum bunting dapat segera dikawinkan kembali. "Hal ini bisa memperpendek masa kosong atau kering dan sapi induk yang telah secara dini diketahui bunting dapat segera dipelihara secara lebih baik untuk menjaga dan menyelamatkan kebuntingan sampai lahir dengan selamat. Disamping itu peternak juga dapat meningkatkan efisiensi reproduksi sapi dan menekan biaya produksi. Ada baiknya program ini diintegrasikan dengan program SIWAB untuk meningkatkan kebuntingan sapi yang menjadi keunggulan Kementerian Pertanian dalam upaya meningkatkan populasi dan produktivitas sapi di daerah Kinali Pasaman Barat ini.
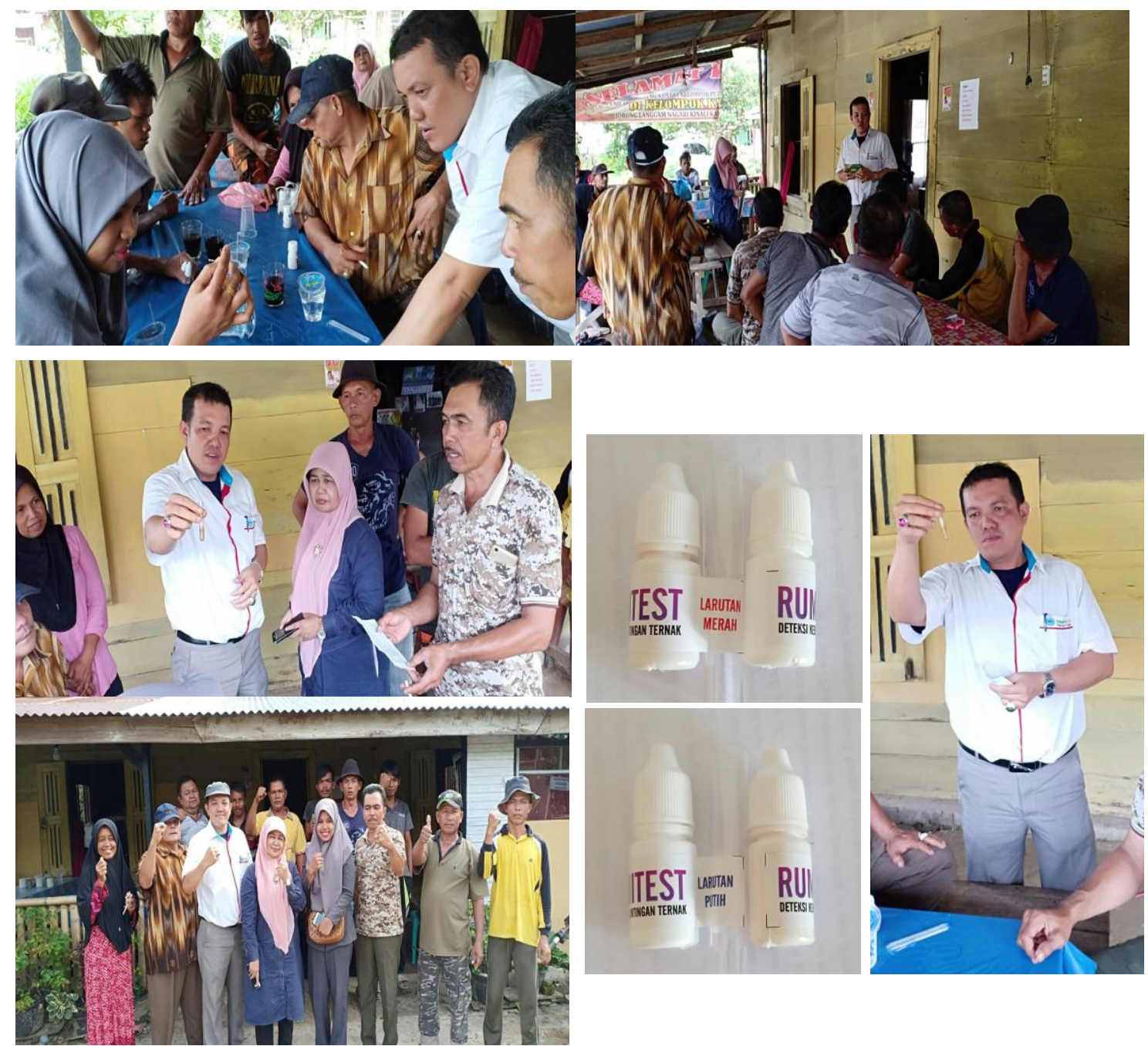

Gambar 2. Demonstrasi Teknologi Deteksi Kebuntingan Dini Pada Sapi Potong

\section{Teknologi Inovasi Pakan Ramah Lingkungan}

Pakan utama ternak sapi adalah rumput segar untuk menunjang produksi disamping pakan penguat (konsentrat). Dalam hal pemberian pakan, masih banyak peternak yang 
memberikan pakan ternak seadanya, pada hal di sekitar wilayah tersebut banyak ditemukan berbagai hijauan/tanaman yang mempunyai nilai gizi tinggi dan dapat dimanfaatkan sebagai makanan ternak.

Ketersediaan pakan khususnya pakan hijauan merupakan faktor yang penting dalam menentukan keberhasilan usaha peternakan ternak ruminansia. Hal ini disebabkan hampir $90 \%$ pakan ternak ruminansia berasal dari hijauan dengan konsumsi segar perhari $10-15 \%$ dari berat badan, sedangkan sisanya adalah konsentrat dan pakan tambahan (feed supplement) Pakan ternak ruminansia selama ini diperoleh dan bersumber dari padang pengembalaan. Beberapa tahun terakhir padang pengembalaan mengalami penurunan produktivitas, kondisi tersebut dipengaruhi oleh menurunnya areal padang yang dipengaruhi oleh perubahan fungsi lahan. Dengan demikian potensi padang pengembalaan sebagai penyedian hijauan pakan juga mengalami penurunan. Oleh karena itu perlu adanya alternatif untuk memenuhi kebutuhan tersebut, paling tidak dengan memamfaatkan lahan-lahan pertanian untuk pengembangan penanaman hijauan yang unggul secara terpadu.
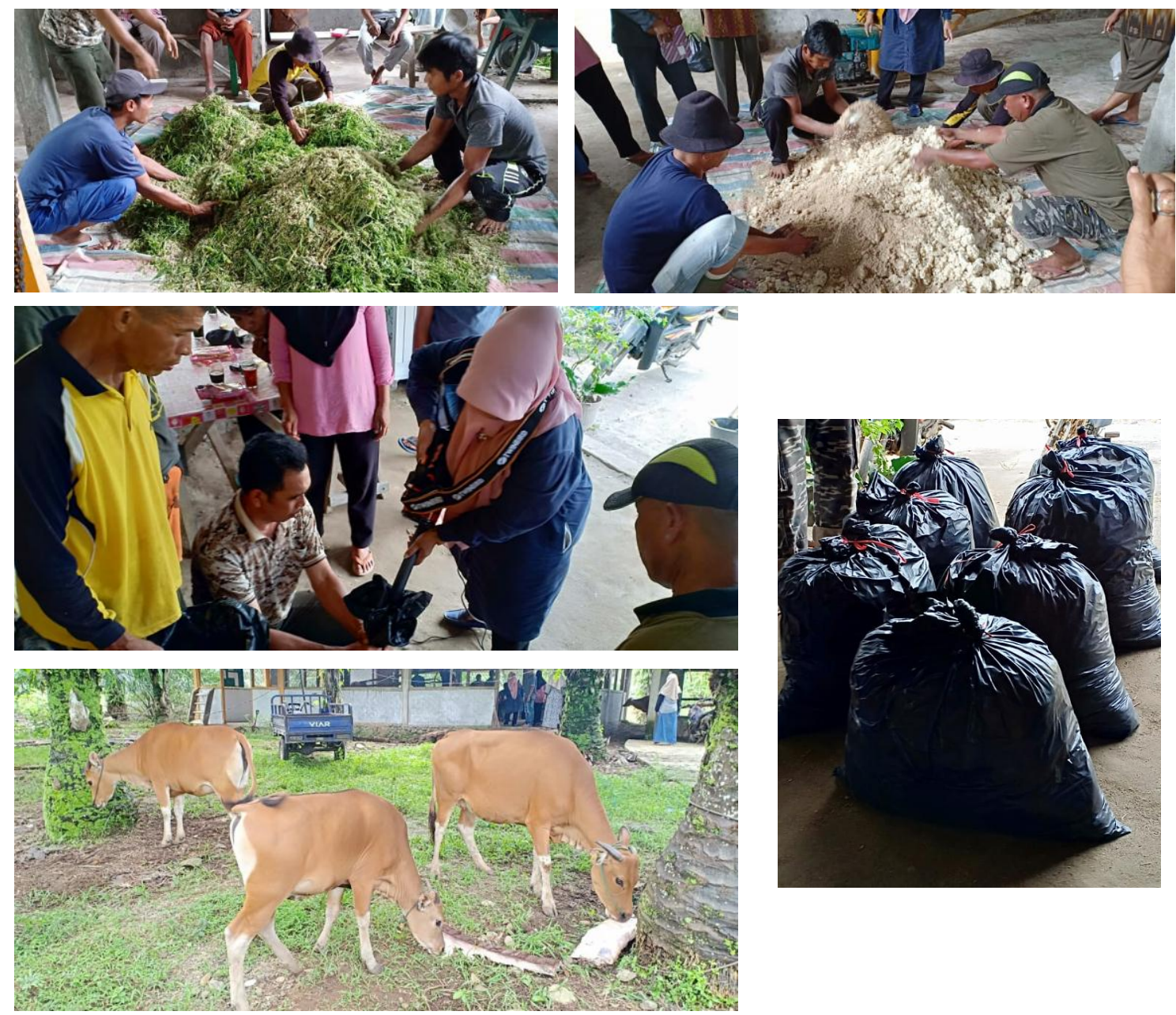

Gambar 3. Demonstrasi Pembuatan Ransum Komplit 
Peternak juga mendapatkan penjelasan tentang pentingnya pemberian pakan penguat berupa konsentrat pada ternak induk terutama pada masa sebelum masa perkawinan ternak, sebulum dan setelah melahirkan agar produktifitas ternak tetap baik. Kalau ada kejadian ternak yang terlalu kurus, maka perlu diberikan pakan tambahan berupa konsentrat.

Faktor pembatas pemanfaatan limbah sebagai pakan ternak secara umum meliputi kualitas nutrisi yang rendah akibat kandungan serat yang tinggi, kandungan antinutrisi dan kadar air bahan yang tinggi. Perlakuan yang paling umum dilakukan terhadap limbah yang dapat digunakan untuk bahan pakan ternak diantaranya berupa perlakuan secara fisik, kimia, biologis dan atau kombinasi perlakuan fisiko-kimia atau fisiko-biologis.

Ransum juga dibuat dalam bentuk ransum komplit dan dapat disimpan dalam jangka waktu tertentu dengan cara memasukkan ransum yang sudah dicampur ke dalam karung kapasitas 20-40 kg tempat penyimpana yang telah dilapisi dengan kantong plastik pada bagian dalamnya, kemudian dihisap dengan menggunakan pompa vakum selama \pm 10 menit. Kemudian kantong diikat dengan tali karet untuk membuat kondisi menjadi anaerob. Kantong selanjutnya disimpan pada tempat yang teduh sampai ransum akan digunakan sesuai kebutuhan ternak.

Dilakukan percontohan tentang: 1) teknik penyusunan ransum. 2) teknik pembuatan dan pengadukan ransum konsentrat dan ransum komplit. Formulasi ransum dilakukan berdasarkan data kandungan nutrien bahan pakan dan standar kebutuhan ternak sapi. Kegiatan formulasi ransum dilakukan oleh tim pelaksana dan didiskusikan dengan kelompok.

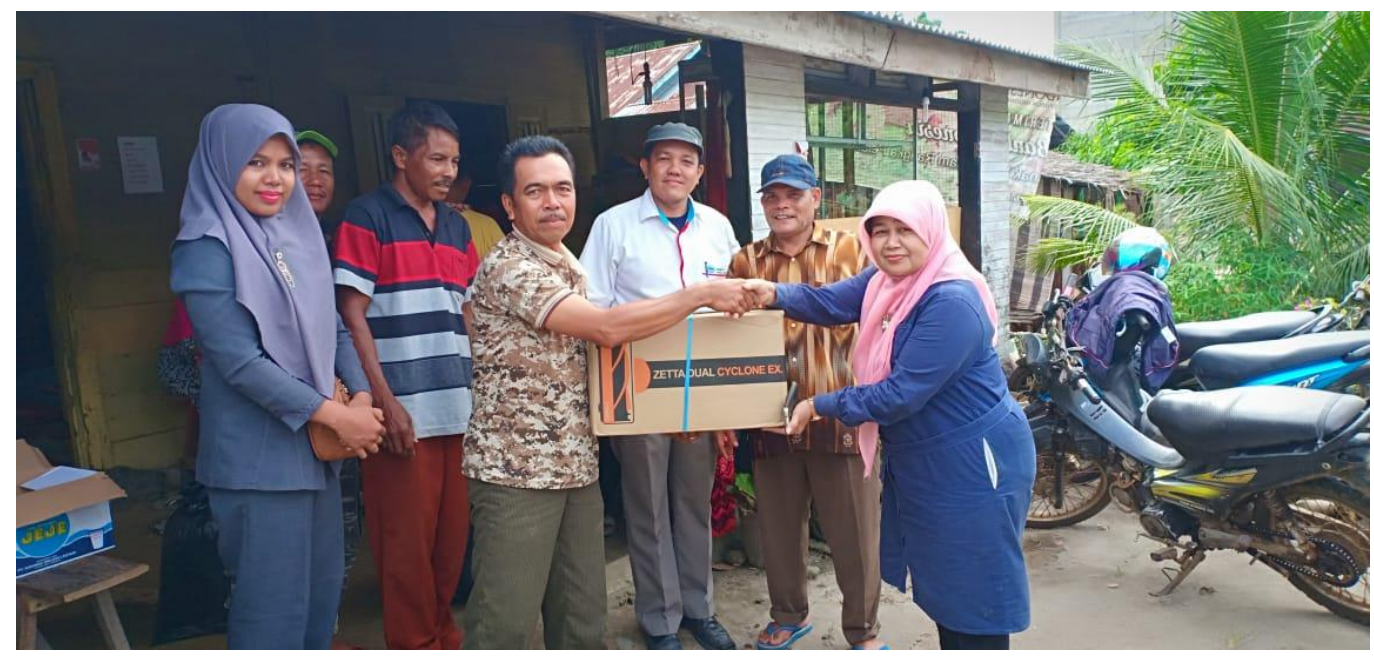

Gambar 4. Penyerahan Alat Vacum untuk Pembuatan Teknologi Silase dan Ransum Komplit

\section{KESIMPULAN DAN SARAN}

\section{Kesimpulan}

Berdasarkan tahapan kegiatan yang sudah dilakukan dan hasil evaluasi kegiatan dapat disimpulkan bahwa meningkat pengetahuannya tentang teknik budidaya sapi potong yang baik yang berbasis menguntungkan dan mampu melakukan teknologi 
deteksi kebuntingan dini pada sapi potong mereka. Disamping itu, peternak juga meningkat kemampuannya dalam formulasi ransum sehingga kebutuhan nutrisi ternak dapat terpenuhi sesuai standar kebutuhan ternak. Selanjutnya, proses pembuatan complete feed fermentasi limbah pertanian dinyatakan berhasil dan dapat diaplikasikan sebagai bahan pakan ternak sapi.

\section{UCAPAN TERIMA KASIH}

Ucapan terima kasih diucapkan kepada Rektor Universitas Andalas dan LPPM Unand yang telah mendanai kegiatan ini melalui dana BOPTN tahun anggaran 2018. Selanjutnya ucapan terimakasih disampikan kepada tokoh masyarakat dan kelompok tani Karya Muda dan Usaha Muda di Kinali, Pasaman Barat.

\section{DAFTAR PUSTAKA}

Baba, S. dan M. Risal. 2014. Preferensi dan tingkat pengetahuan peternak tentang teknologi IB di Kabupaten Barru. Prosiding Seminar Nasional Peningkatan Produktivitas Ternak Lokal, Abstrak. Makassar, 9 Oktober 2014.

Efrizal., Rusnam dan F.L. Syaiful. 2018. Diseminasi teknologi pembuatan pakan buatan alternatif dengan campuran limbah kangkung air, Ipomoea aquatica Forks untuk pembudidaya ikan di Sumatera Barat. Jurnal Hilirisasi IPTEKS. 1(3): 1-10.

Hafez, E.S.E. 2000. Reproduction in Farm Animals. $7^{\text {th }}$ Ed. Lippincott Williams and Wilkins, Philadelphia.

Inounu, I., N. Hidayati, A. Priyanti dan B. Tiesnamurti. 2002. Peningkatan Produktivitas Domba melalui Pembentukan Rumpun Komposit. Buku I Ternak Ruminansia. Balai Penelitian Ternak, Ciawi, Bogor.

Samsudewa, D., A. Lukman dan E. Sugianto. 2003. Identifikasi ion fenol dalam urine sebagai alternatif metode deteksi kebuntingan ternak. Lomba Karya Inovatif Mahahasiswa 2003. Universitas Diponegoro, Semarang.

Sowmen, S., Khasrad dan Rusdimansyah. 2018. Introduksi IPTEKS pada peternakan sapi di kelompok tani rawang saiyo dan kelompok tani tuah sepakat. Jurnal Hilisasi IPTEKS. 1(3): 43-49.

Syaiful F.L. 2018. Diseminasi teknologi deteksi kebuntingan dini "DEEA GestDect" terhadap sapi potong di Kinali Kabupaten Pasaman Barat. Jurnal Hilisasi IPTEKS. 1(3): 17-25 
Syaiful. F.L., U.G.S. Dinata dan Ferido. 2018. Pemberdayaan masyarakat Nagari Sontang Kabupaten Pasaman melalui inovasi budidaya sapi potong dan inovasi pakan alternatif yang ramah lingkungan. Buletin Ilmiah Nagari Membangun. 1(3): 21-31

Syaiful. F.L., U.G.S. Dinata dan Y. Hidayattullah. 2018. Pemberdayaan masyarakat melalui pemanfaatan limbah sekam padi sebagai bahan bakar kompor sekam yang ramah lingkungan di kinali, pasaman barat. Buletin Ilmiah Nagari Membangun. 1(3): $62-69$

Syaiful, F.L. 2018. Pemberdayaan masyarakat melalui budidaya sapi potong terintegrasi sawit dan penanaman rumput gajah sebagai bahan pakan ternak di nagari Kinali Kabupaten Pasaman Barat. Unes Journal of Community Service. 2(2): 142-149.

Syaiful, F.L. 2018. Optimalisasi inseminasi buatan sapi potong melalui akurasi kebuntingan dini terhadap uji punyakoti dan palpasi rektal. Jurnal Embrio. 10(2): 41-48.

Triwulaningsih, E., T. Susilawati, dan Kustono. 2009. Reproduksi dan Inovasi Teknologi Reproduksi: Profil Usaha Peternakan Sapi Perah di Indonesia. Pusat Penelitian dan Pengembangan Pertanian, Jakarta. 